\title{
True branched nostocalean cyanobacteria from tropical aerophytic habitats and molecular assessment of two species from field samples
}

\author{
Viviani Ferreira ${ }^{1}$, Luis Henrique Z. Branco ${ }^{1,2} \&$ Jan Kaštovský ${ }^{3}$ \\ 1. Microbiology Graduation Program, UNESP-São Paulo State University, IBILCE, São José do Rio Preto, SP, Brazil; \\ viviani_bio@yahoo.com.br \\ 2. UNESP-São Paulo State University, IBILCE, Department of Zoology and Botany, R. Cristóvão Colombo, 2265, \\ BR-15054-000, São José do Rio Preto, SP, Brazil; branco@ibilce.unesp.br \\ 3. University of South Bohemia, Department of Botany, Branišovská, 31a, 370 05, České Budějovice, Czech Republic; \\ hanys@prf.jcu.cz
}

\author{
Received 13-II-2012. Corrected 10-VIII-2012. Accepted 11-IX-2012.
}

\begin{abstract}
Aerophytic cyanobacteria are commonly found growing on rocks, tree trunks and soil, but the diversity of these organisms is still poorly known. This complex group is very problematic considering the taxonomic arrangement and species circumscription, especially when taking into account tropical populations. In this work, 20 samples of aerophytic cyanobacteria from 15 distinct sampling sites were collected along a tropical rainforest area at the São Paulo State (Brazil). Samples were dried at room temperature after the collection, and once in the laboratory, they were rehydrated and analyzed. The taxonomic study resulted in the record and description of nine species of true-branched cyanobacteria pertaining to the genera Spelaeopogon (one specie), Hapalosiphon (two species) and Stigonema (six species). The similarity of the flora found when compared to surveys conducted in other geographical regions was relatively low. These differences could be addressed to ecological conditions of the habitats, to the extension of the area surveyed or even to taxonomic misinterpretations. The molecular assessment of $16 \mathrm{~S}$ rDNA on the basis of field material was successful for two morphospecies, Hapalosiphon sp. and Stigonema ocellatum; however, their relationships with other populations and species revealed to be uncertain. The results of the floristic survey and of the molecular approach evidenced the fragile delimitation of some genera and species in the true branched group of cyanobacteria. Rev. Biol. Trop. 61 (1): 455-466. Epub 2013 March 01.
\end{abstract}

Key words: 16S rDNA, Brazil, Nostocales, diversity, "Stigonematales", tropical rainforest, taxonomy.

True branched nostocalean cyanobacteria (formerly Stigonematales) are the most evolved prokaryotes regarding thallus organization and cell differentiation (Golubić 1976). These organisms are common in terrestrial habitats and the inner taxonomy is problematic, especially when tropical populations are included. Anagnostidis \& Komárek (1990) classified the true branching cyanobacteria in the order Stigonematales with eight families and 48 genera. The order was characterized by the occurrence of true branched filaments and heterocytes and the below order taxa were defined by filament structure, true branching type, heterocyte position and reproduction strategies.

The classification system proposed by Hoffmann et al. (2005) to Cyanobacteria merged the former Nostocales and Stigonematales into Nostocales, after several studies have pointed out that branching type has no phylogenetic value for distinguishing orders. The presence of heterocytes, however, supports phylogeny and indicates the monophyly of the group (Seo \& Yokota 2003, Gugger \& Hoffmann 2004). Further contributions to the classification of cyanobacteria (Komárek 2006, 
2010) have supported the systematic arrangement proposed by Hoffmann et al. (2005) for this group of organisms.

The taxonomy of cyanobacteria is now based on polyphasic approach including morphological characters (e.g., cell division and polarity, branching type and thallus morphology), molecular data, ultrastructural arrangement (mainly thylakoids) and ecological parameters, which are combined to define groups. However, the developmental biology of the true branched cyanobacteria is still in the early stages of knowledge (Finsinger et al. 2008). The problems related to the artificial cultivation of most of true branched cyanobacteria samples (e.g. environmental exigencies not totally understood, slow growth and low competitive ability under artificial conditions prior to isolation) difficult the assessment of morphological variability and molecular sequencing by the most common and regular methods.

Taxonomic studies on true branched cyanobacteria are not abundant. The few papers devoted to the knowledge of these organisms include just some genera (e.g., Capsosira, Chlorogloeopsis, Fischerella, Nostochopsis, Stigonema and Westiellopsis) with reduced number of species, mainly about populations from temperate regions, and, in fact, this is considered not sufficient to solve the evolutionary history of the true branched cyanobacteria (Tomitani 2004).

Some of the most extensive surveys of tropical aerophytic cyanobacteria that include true branched taxa are those of Gardner (1927), Kufferath (1929), Golubić (1967), Hoffmann (1986), Sarthou et al. (1995), Büdel et al. (1994, 1997, 2002), Couté et al. (1999), Pattanaik \& Adhikary (2002) and Kaštovský et al. (2011). Surveys of the Brazilian flora of true branched cyanobacteria (including those from freshwater habitats) are very scarce and practically restricted to the papers of Silva \& Sant'Anna (1991, 1996). The contributions of Branco \& Necchi-Júnior (1999) and Branco et al. (2010) focused single true branched freshwater species (Doliocatella formosa and
Pulvinularia suecica, respectively) occurring in Brazilian territory.

This paper aims to improve the taxonomic knowledge of an ecologically and evolutionary important group of organisms and to describe morphological and habitat data of species present in a tropical region. In addition, the molecular assessment from field samples constitutes a complementary objective in order to improve the characterization of the populations found.

\section{MATERIALS AND METHODS}

Detailed information on sampling area, as well as on collection, preservation and characterization of sites, samples and taxonomic study are described in Branco et al. (2009). Briefly, samples of true branched cyanobacteria were collected in the rainforest region along the Northern littoral area of the São Paulo State (Table 1). Visible growths of cyanobacteria on soil, tree trunks and rocky substrates were randomly collected with spatula or penknife. The samples were stored in paper bags and dried at room temperature (usually for 24 to $48 \mathrm{~h}$ ). For each collection (sometimes different samples-coded SAMA-were taken from the same site), data about global position and altitude (GPS Garmin, eTrex Summit), air and plant-mass temperature (as close as possible to the growths) (digital thermometer with a $11 \mathrm{~cm}$ long metal probe), air and plant-mass humidity (ThermoHygrometer Hana Instruments, HI8564), total and relative irradiance (Li-Cor Quantameter, with spherical sensorthe relative values are a relation between the absolute value measured as close as possible to the mass by the absolute value measured at an open area) and substratum $\mathrm{pH}$ (Merck $\mathrm{pH}$ strips-pH was measured through a solution with distilled/deionized water and a sample of the substratum) of collection sites and samples were recorded.

In the laboratory, samples were rehydrated and then examined under stereoscope (Olympus SZX7) and light (Olympus BX-50) microscopes and microphotographs were taken by using a digital camera (Olympus DP71) 
TABLE 1

Global position and altitude of the collection sites and their respective samples

\begin{tabular}{|c|c|c|c|c|}
\hline Site & Sample & Latitude (S) & Longitude (W) & Altitude (m) \\
\hline 01 & SAMA 01 & $23^{\circ} 35^{\prime} 51^{\prime \prime}$ & $46^{\circ} 10^{\prime} 08^{\prime \prime}$ & 800 \\
\hline 02 & SAMA 02 & $23^{\circ} 41^{\prime} 07^{\prime \prime}$ & $46^{\circ} 05^{\prime} 52^{\prime \prime}$ & 791 \\
\hline 03 & SAMA 04 & $23^{\circ} 41^{\prime} 09^{\prime \prime}$ & $46^{\circ} 05^{\prime} 52^{\prime \prime}$ & 787 \\
\hline 04 & SAMA 10 & $23^{\circ} 46^{\prime} 21^{\prime \prime}$ & $45^{\circ} 57^{\prime} 14^{\prime \prime}$ & 22 \\
\hline 05 & SAMA 13 & $23^{\circ} 46^{\prime} 14^{\prime \prime}$ & $45^{\circ} 43^{\prime} 14^{\prime \prime}$ & 55 \\
\hline 08 & SAMA 22 & $23^{\circ} 36^{\prime} 10^{\prime \prime}$ & $45^{\circ} 26^{\prime} 43^{\prime \prime}$ & 183 \\
\hline 09 & SAMA 09 & $23^{\circ} 30^{\prime} 34^{\prime \prime}$ & $45^{\circ} 07^{\prime} 56^{\prime \prime}$ & 0 \\
\hline 10 & SAMA 23, SAMA 24 & $23^{\circ} 35^{\prime} 16^{\prime \prime}$ & $45^{\circ} 26^{\prime} 57^{\prime}$ & 600 \\
\hline 13 & SAMA 33 & $23^{\circ} 32^{\prime} 56^{\prime \prime}$ & $45^{\circ} 14^{\prime} 47^{\prime \prime}$ & 23 \\
\hline 14 & SAMA 34, SAMA 35, SAMA 36, SAMA 37 & $23^{\circ} 29^{\prime} 39^{\prime \prime}$ & $45^{\circ} 08^{\prime} 38^{\prime \prime}$ & 66 \\
\hline 15 & SAMA 38 & $23^{\circ} 23^{\prime} 06^{\prime \prime}$ & $45^{\circ} 07^{\prime} 19^{\prime \prime}$ & 122 \\
\hline 18 & SAMA 45 & $23^{\circ} 22^{\prime} 37^{\prime \prime}$ & $45^{\circ} 07^{\prime} 07^{\prime \prime}$ & 309 \\
\hline 19 & SAMA 48, SAMA 49 & $23^{\circ} 24^{\prime} 50^{\prime \prime}$ & $45^{\circ} 01 ’ 43^{\prime \prime}$ & 77 \\
\hline 21 & SAMA 53 & $23^{\circ} 10^{\prime} 52^{\prime \prime}$ & $44^{\circ} 50^{\prime} 00^{\prime \prime}$ & 1239 \\
\hline 22 & SAMA 54 & $23^{\circ} 09^{\prime} 54^{\prime \prime}$ & $44^{\circ} 50^{\prime} 21^{\prime \prime}$ & 1460 \\
\hline
\end{tabular}

coupled to the light microscope. Specimens were studied according to their taxonomic features and were identified based on specific literature on cyanobacteria. The classification system by Hoffmann et al. (2005), with the modifications proposed by Komárek (2006), was adopted.

Field samples were selected for molecular analysis and the DNA extractions were made using the "Ultra Clean Microbial DNA Isolation" Kit (MoBio Laboratories). The products were amplified using the primers $27 \mathrm{~F} 1$ and 1494Rc (Neilan et al. 1997) and the "Pure Taq Ready To-Go PCR Beads" kit (GE Life Science). Reactions were cycled with an initial denaturation step at $94^{\circ} \mathrm{C}$ for $4 \mathrm{~min}$, followed by 30 cycles of denaturation at $94^{\circ} \mathrm{C}$ for $20 \mathrm{sec}$, annealing at $50^{\circ} \mathrm{C}$ for $30 \mathrm{sec}$, extension at $72^{\circ} \mathrm{C}$ for $2 \mathrm{~min}$ and final extension step at $72^{\circ} \mathrm{C}$ for $7 \mathrm{~min}$. PCR products were purified with Wizard PCR Preps DNA Purification System (Promega) and cloned by using the "pGEM ${ }^{\circledR}-\mathrm{T}$ Easy Vector Systems" Kit (Promega). Vector with the insert was introduced by thermal shock (Sambrook et al. 1989) in competent Escherichia coli $\mathrm{DH} 5 \alpha$ cells. Plasmids with the interested insert were purified by alkaline hydrolysis (Birnboim \& Doly 1979) and amplified with "DYEnamic ET Terminator Cycle Sequencing" Kit (Amersham Biosciences, Piscataway, NJ, EUA). M13F and SP6R vector primers and 357F, 357R, 704F, 704R, 1114F and 1114R internal primers (Lane, 1991) were used to select DNA sequences of about $1500 \mathrm{bp}$.

Products were sequenced (in triplicates and both directions) in an ABI PRISM ${ }^{\circledR} 3100$ Genetic Analyzer Applied Biosystems) and the nucleotide sequences obtained were aligned, refined and edited using the software BioEdit v 7.0.5 (Hall 1999). The two sequences produced in this study were compared to other 19 sequences of 16S rRNA gene retrieved from GenBank (NCBI), mostly representing taxonomically similar genera.

Phylogenetic trees were constructed by neighbor-joining (NJ; using SeaVIEW4 software), maximum likelihood (ML; PhyML 3.0) and Bayesian inference (BI; Mr. Bayes 3.12). Bootstrap values for neighbor-joining and maximum likelihood were generated on the basis of 1000 replicates and Bayesian probability was based on two million generations. The evolution model used was GTR as suggested by Treefinder (version March 2011). 


\section{RESULTS}

Environmental data: Values of the parameters were variable, but the ranges of species occurrence were mostly overlapped (Table 2). Values of $\mathrm{pH}$ ranged from 4-5, but reached up to 10 ; the values higher than five were observed for the lime painted hard substrates (rocks or cement curbs) where some populations were growing on. Total irradiance values oscillated from $300-2740 \mu \mathrm{mol}$ photons $/ \mathrm{m}^{2} / \mathrm{s}$ and the relative values $(2-100 \%)$ showed the occurrence of populations in open to shaded sites. Air relative humidity was usually high, ranging from $60-92 \%$, but always slightly lower than the values observed close to the plant masses (62-94\%).

Floristic survey: Nine true branched nostocalean species, pertaining to three families, were found in the 20 samples from 15 distinct sites along the studied area (Table 1).

\section{Borzinemataceae}

\section{Spelaeopogon sommierii}

Borzi, Nuovo Giorn. Bot. Ital. 24: 108, 1917. (Fig. 1)

Plant mass formed by entangled filaments, caespitose, sometimes isolate filaments or in small groups in the mucilage of other cyanobacteria; main filament and branches similar; filaments usually uniseriate, occasionally biseriate, $10.0-11.0 \mu \mathrm{m}$ wide, irregularly T-branched, Y-false branching present; sheath thin, hyaline; trichomes constricted, sometimes not constricted, 8.0-10.0(-13.0) $\mu \mathrm{m}$ wide; cells cylindrical to rounded, $10.0-12.0(-15.0)$ $\mu \mathrm{m}$ long; heterocytes intercalary or apical, 9.016.0 $\mu \mathrm{m}$ long, (8.0-)10.0-12.0(-13.0) $\mu \mathrm{m}$ wide. Occurrence: $\mathrm{n}=1$; SAMA 09 .

\section{Mastigocladaceae}

Hapalosiphon cf. aureus W. West \& G.S. West, J. Bot. 35: 241, 1897. (Fig. 2)

Plant mass formed by entangled filaments, caespitose; main filament and branches similar or with slightly distinct in diameter; filaments uniseriate, 7.0-15.0(-17.5) $\mu \mathrm{m}$ wide; branches usually on one side of the filament; sheath thin to moderately thick, hyaline to yellowish brown; trichomes constricted, $5.0-13.0 \mu \mathrm{m}$ wide; cells 4.0-10.0(-12.0) $\mu \mathrm{m}$ long, $0.4-1.5$ times longer than wide; cell content granulated, blue-green; heterocytes not abundant, 6.09.3 $\mu \mathrm{m}$ long, 5.5-6.8 $\mu \mathrm{m}$ wide.

Occurrence: $\mathrm{n}=1$, SAMA 01 .

Note: This population corresponds well to the description of Hapalosiphon aureus,

TABLE 2

Values (or range) of selected ecological parameters of the sites where the species were found

\begin{tabular}{lccccccccc} 
& $\mathrm{n}$ & $\mathrm{AT}$ & $\mathrm{MT}$ & $\mathrm{ARH}$ & $\mathrm{MRH}$ & $\mathrm{Ir}$ & $\mathrm{Pir}$ & $\mathrm{pH}$ & $\mathrm{S}$ \\
Spelaeopogon sommierii & 1 & $*$ & $*$ & $*$ & $*$ & $*$ & $*$ & $*$ & rock \\
Hapalosiphon cf. aureus & 1 & 19.6 & 19.9 & 85 & 90 & 110 & 29 & 5 & soil \\
Hapalosiphon sp. & 1 & 22.3 & 21.5 & 92 & 94 & 43 & 66 & 5 & soil \\
Stigonema hormoides & 9 & $21.1-30.6$ & $19.5-38.4$ & $59-92$ & $67-94$ & $35-2740$ & $2-100$ & $4-5$ & rock, soil \\
S. informe & 1 & 24.6 & 25.5 & 80 & 87 & 160 & 51 & 5 & rock \\
S. minutum & 4 & $21.9-27.7$ & $19.5-36.0$ & $55-86$ & $62-89$ & $14-1700$ & $3-100$ & $4-5$ & rock, soil \\
S. ocellatum & 12 & $19.6-31.0$ & $18.3-38.0$ & $62-83$ & $70-87$ & $25-2740$ & $5-100$ & $4-10$ & rock, soil \\
S. turfaceum & 5 & $21.8-27.7$ & $20.0-23.9$ & $74-90$ & $75-93$ & $3-330$ & $5-48$ & $4-5$ & rock, soil \\
Stigonema sp. & 1 & 24.6 & 25.5 & 80 & 87 & 160 & 5 & 5 & rock \\
\hline
\end{tabular}

* data not available. $\mathrm{n}=$ number of samples with species record, $\mathrm{AT}=$ air temperature $\left({ }^{\circ} \mathrm{C}\right), \mathrm{MT}=$ plant mass temperature $\left({ }^{\circ} \mathrm{C}\right)$, $\mathrm{ARH}=$ relative humidity of the air (\%), MRH=relative humidity close to the plant mass (\%), Ir=irradiance measured close to the plant mass $\left(\mu \mathrm{mol}\right.$ photons $\left./ \mathrm{m}^{2} / \mathrm{s}\right), \mathrm{PIr}=$ percentage of irradiance reaching the plant mass in relation to the irradiance at a near open site $(\%), S=$ substratum type. 

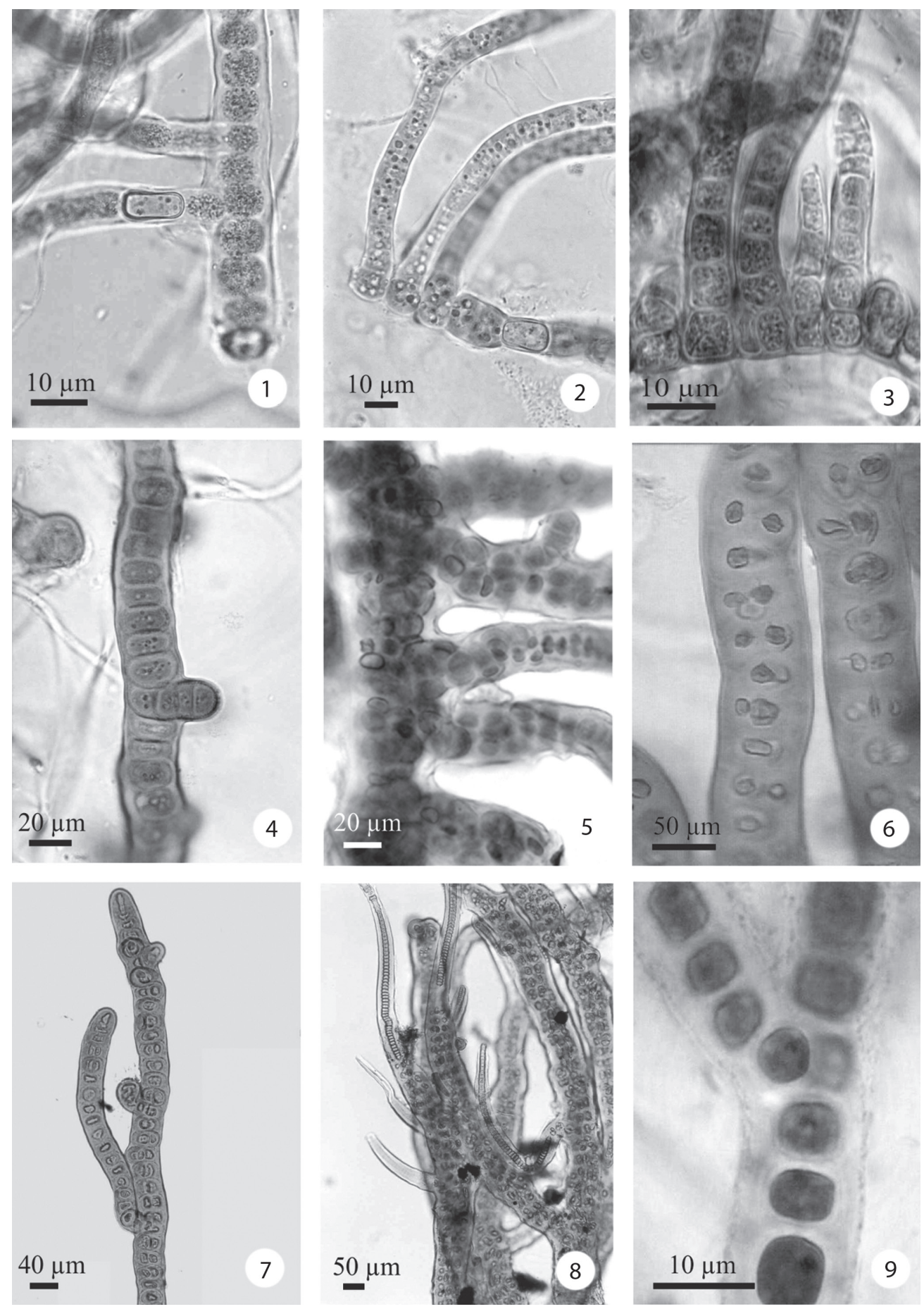

Figs. 1-9. (1) Spelaeopogon sommierii. (2) Hapalosiphon cf. aureus. (3) Hapalosiphon sp. (4) Stigonema hormoides. (5) S. informe. (6) S. minutum. (7) S. ocellatum. (8) S. turfaceum. (9) Stigonema sp. 
but differs from it by its shorter cells in the branches and by its biotope characteristics. $H$. aureus is known from aquatic habitats, inhabiting standing water bodies, while the studied population is aerophytic on soil in tropical rainforest.

\section{Hapalosiphon sp. (Fig. 3)}

Plant mass formed by densely entangled filaments, prostrate; main filament and branches similar; filaments uniseriate, 6.0-9.0(10.7) $\mu \mathrm{m}$ wide; branches long, usually on one side of the filament, not narrowing at the apex; sheath thin to moderately thick, hyaline to yellowish brown; trichomes constricted, 4.0-7.6 $\mu \mathrm{m}$ wide; cells 3.5-7.0(-10.5) $\mu \mathrm{m}$ long, 0.7-1.3(-2.3) times longer than wide; cell content granulated, pale green to pale blue-green; heterocytes frequent, cylindrical to sub-quadrate, $4.0-8.5(-10.0) \mu \mathrm{m}$ long, $5.0-8.0 \mu \mathrm{m}$ wide; arthrospores cylindrical to rounded, sometimes in long chains, usually with one (or more) big refringent granule (oil?) inside, $8.0-11.0 \mu \mathrm{m}$ long, $5.5-7.0 \mu \mathrm{m}$ wide, epispore thick, smooth, dark yellowish brown.

Occurrence: $\mathrm{n}=1$, SAMA 45.

Note: this population resembles Hapalosiphon welwitschii in filament diameter, however heterocytes are rare and, mainly, the branches are short and tapered in this species.

\section{Stigonemataceae}

Stigonema hormoides Bornet \& Flahault, Ann. Sci. nat., 7, 5: 68, 1887. (Fig. 4)

Plant mass formed by entangled filaments, erect, yellowish brown or dark brown, or filaments grouped or growing isolated in gelatinous masses of other cyanobacteria; main filament and branches distinct; filaments with one row of cells, rarely two, (7.0-)9.0-17.5(22.0) $\mu \mathrm{m}$ wide; branches usually short; sheath thick, yellowish to yellowish brown; cells variable, discoid, spherical, oval, squarish, rounded or irregular, 2.4-9.6(-14.0) $\mu \mathrm{m}$ long, $(-2.5) 4.0-12.0 \mu \mathrm{m}$ wide; cell content granulated, blue-green; heterocytes hemispherical or rounded, lateral or intercalar, 4.0-9.6 $\mu \mathrm{m}$ long, $3.2-9.6 \mu \mathrm{m}$ wide; homorgones terminal in the branches, 25.0-30.0(-70.0) $\mu \mathrm{m}$ long.

Occurrence: $n=9$, SAMA 04, SAMA 22, SAMA 33, SAMA 34, SAMA 35, SAMA 36, SAMA 38, SAMA 45, SAMA 54.

Note: According to literature data, S. hormoides is distributed along tropical and temperate regions and its metrical and morphological ranges are relatively wide.

\section{Stigonema informe}

Kützing ex Bornet \& Flahault, Ann. Sci. nat., 7, 5: 75, 1887. (Fig. 5)

Plant mass formed by entangled filaments, caespitose, yellowish to yellowish brown; main filament and branches distinct; main filaments with up to four rows of cells, 56.0$87.4 \mu \mathrm{m}$ wide; branches $24.0-44.0 \mu \mathrm{m}$ wide; sheath thick, yellowish to yellowish brown; cells hemispherical to rounded, sometimes grouped forming "packs", 7.2-16.0 $\mu \mathrm{m}$ long, 6.4-12.0 $\mu \mathrm{m}$ wide; cell content granulated, bluegreen; heterocytes hemispherical, lateral, 7.2$12.0 \mu \mathrm{m}$ long, 3.2-11.2 $\mu \mathrm{m}$ wide; homorgones terminal in the branches, short, $16.0-32.0 \mu \mathrm{m}$ long, 6.9-12.0 $\mu \mathrm{m}$ wide.

Occurrence: $\mathrm{n}=1$, SAMA 38 .

Stigonema minutum Bornet \& Flahault, Ann. Sci. nat., 7, 5: 72, 1886. (Fig. 6)

Plant mass formed by entangled filaments, caespitose (main filament prostrate and branches erect); main filament and branches distinct; main filaments with up to three rows of cells, $20.0-28.0 \mu \mathrm{m}$ wide; branches up to two rows of cells, not enlarging or tapering towards to the end, 14.0-18.2(-20.0) $\mu \mathrm{m}$ wide; sheath thick, yellowish to yellowish brown; cells discoid to hemispherical, 5.0-12.0(-15.0) $\mu \mathrm{m}$ long, 5.0-13.0 $\mu \mathrm{m}$ wide; cell content granulated, bluegreen; heterocytes hemispherical, lateral, 7.0$11.0 \mu \mathrm{m}$ long, $6.0-13.0 \mu \mathrm{m}$ wide; homorgones terminal in the branches, short.

Occurrence: $n=4$, SAMA 24, SAMA 36, SAMA 48, SAMA 54. 
Note: The species is commonly referred in literature with distinct morphotypes. In addition, populations identified as $S$. minutum are recorded occurring in very distinct climate regions, from temperate (type material) to tropical or even polar areas. Species revision is probably needed.

\section{Stigonema ocellatum}

Thuret ex Bornet \& Flahault, Ann. Sci. nat., 7, 5: 69, 1887. (Fig. 7)

Plant mass formed by entangled filaments, erect or filaments grouped or isolated growing in gelatinous masses of other cyanobacteria; main filament and branches similar; filaments with one row of cells, occasionally two, 18.7-45.0 $\mu \mathrm{m}$ wide; sheath thick, yellowish to yellowish brown; cells variable, irregular, hemispherical, oval, squarish or, more commonly, rounded, 3.0-20.0 $\mathrm{m}$ long, 4.0$25.6 \mu \mathrm{m}$ wide; cell content granulated, bluegreen; heterocytes discoid, hemispherical or rounded, lateral, 8.7-21.6 $\mu \mathrm{m}$ long, 6.4-22.4 $\mu \mathrm{m}$ wide; homorgones terminal in the branches,

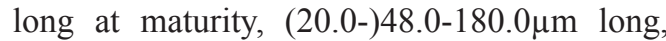
9.6-20.0 $\mu \mathrm{m}$ wide.

Occurrence: $n=12$, SAMA 04, SAMA 10, SAMA 13, SAMA 22, SAMA 23, SAMA 33, SAMA 34, SAMA 35, SAMA 36, SAMA 37, SAMA 38, SAMA 53.

Note: This is one of the most commonly recorded species of the genus Stigonema and the literature data indicate a cosmopolitan distribution, occurring in very distinct types of habitats. As well as, morphological and metrical ranges of $S$. ocellatum are quite wide and some authors (Geitler, 1932) suggest that it is a species complex instead a well-defined taxonomic entity. More detailed studies, including molecular approaches, are surely required to a more precise evaluation.

\section{Stigonema turfaceum}

Cooke ex Bornet \& Flahault,

Ann. Sci. nat., 7, 5: 74, 1887. (Fig. 8)

Plant mass formed by entangled filaments, caespitose; main filament and branches similar; filaments with up to four rows of cells, (20.0-)26.0-35.0(-40.0) $\mu \mathrm{m}$ wide; branches slightly tapering to the apex; sheath thick, yellowish to yellowish brown; cells rounded, 4.8-12.5 $\mu \mathrm{m}$ long, 4.0-11.0 $\mu \mathrm{m}$ wide; cell content granulated, blue-green; heterocytes hemispherical, lateral; homorgones terminal, 9.5-45.0 $\mu \mathrm{m}$ long, 4.0-11.0 $\mu \mathrm{m}$ wide.

Occurrence: $n=5$, SAMA 02, SAMA 34, SAMA 35, SAMA 36, SAMA 49.

\section{Stigonema sp. (Fig. 9)}

Isolated filaments growing mixed with other Stigonema species; main filament and branches similar; filaments with one row of cells, $8.0-12.8 \mu \mathrm{m}$ wide; sheath thick, smooth, hyaline; trichomes $4.0-7.2 \mu \mathrm{m}$ diam.; cells cylindrical, squarish, $2.4-8.0 \mu \mathrm{m}$ long.; cell content yellowish green, homogeneous; heterocytes rare, lateral, $3.1-3.5 \mu \mathrm{m}$ wide, $5.0-5.5 \mu \mathrm{m}$ long; hormogones not observed.

Occurrence: $\mathrm{n}=1$; SAMA 38 .

Note: This population is close to Stigonema hormoides, however the structure of the filament is distinct between them (cylindrical cells in the studied population and usually nearly spherical in $S$. hormoides). In addition, metrics are not fully compatible.

Molecular characterization: Sequencing was tried for all species surveyed, but positive results were obtained only for Hapalosiphon sp. (three clones, $1390 \mathrm{bp}$ ) and Stigonema ocellatum (one clone, $1352 \mathrm{bp}$ ). GenBank accession codes for the new sequences are GQ354274 and GQ354275, respectively.

Phylogenetic analysis on the basis of Hapalosiphon sp. and S. ocellatum sequences and 19 strain sequences retrieved from GenBank resulted in a consensus tree (Fig. 10) with different bootstrap/probability clade values according to the method employed.

The phylogenetic tree shows that both species grouped with heterocytous cyanobacteria, as expected. Stigonema ocellatum grouped with another strain of the same species (SAG 48.90, GenBank access code AJ544082, 98\% 


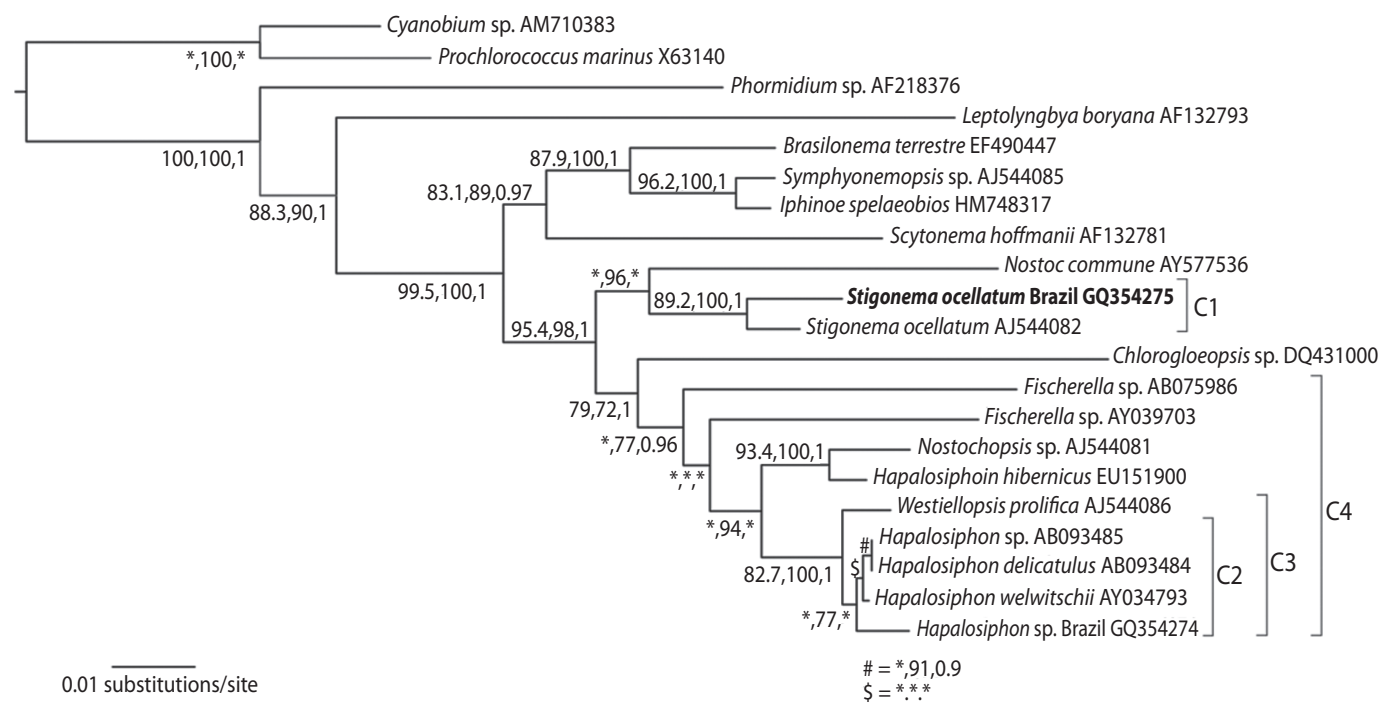

Fig. 10. Consensus phylogenetic tree including the sequences Hapalosiphon sp. and S. ocellatum, from Atlantic rainforest, and 19 strains obtained from GenBank (access numbers are indicate after species name). Values at the nodes are bootstraps for maximum likelihood and neighbor joining (1 000 replications; \%) and probability for Bayesian inference (two million of generations), respectively; only values higher than $70 \%$ or 0.7 are indicated and lower or absent values are indicated by $*$.

sequence similarity) constituting a well-supported cluster $(\mathrm{C} 1)$ with bootstrap/probability values of $89.2 \%, 100 \%$ and 1 (respectively ML, NJ and BI). The two $S$. ocellatum strains are close to a Nostoc commune strain.

Hapalosiphon sp. was similar to $H$. welwitschii (access code AY034793, 98\% sequence similarity) and, according to $\mathrm{NJ}$ test ( $77 \%$ bootstrap), grouped with three other species of the genus (C2), but this group is not formed in ML and BI tests. However, a well-supported clade constituted by Hapalosiphon species and one strain of Westiellopsis prolifica (C3; cluster bootstrap/probability of $82.7 \%, 100 \%$ and 1 for ML, NJ and BI, respectively) was consistently formed in all tests performed. This Hapalosiphon/Westiellopsis clade is nested in a major group (C4; 77\% and 0.96 for NJ and BI, respectively) that includes other morphologically similar genera (Fischerella, Nostochopsis and Chlorogloeopsis) spread in the clade.

\section{DISCUSSION}

Results on spatial distribution reveal that some species were well distributed throughout the sampling area (Stigonema ocellatum, 12 different samples, nine distinct sites; $S$. hormoides, nine samples, six sites), while some are geographically more restricted (Spelaeopogon somierii, Hapalosiphon cf. aureus, Hapalosiphon sp., Sigonema informe and Stigonema sp., all of them occurring in just one sample). The ecological data obtained, however, do not permit to address any conclusion on the species environmental preferences or tolerances. As most of measurements are punctual and too variable (e.g. light) or reasonably homogeneous in rainforest area (e.g. temperature, humidity), those data must be used as a reference for habitat characterization, but not as habitat definition. Nevertheless, the more widespread species occurred under wider 
ranges of variation for most parameters evaluated, as obviously expected.

All the species with occurrence in two or more samples were found growing on different substrate types (soil and rock) and substrate fidelity was not observed for any species recorded. Even though there are species with restricted dependence or preference on a determined substrate, frequently it is not possible to establish a clear relationship between the species and the substrate, especially for the most widespread and morphologically variable species. Unfortunately, there were not found studies in literature developing this subject in detail and more robust conclusions and comparisons cannot be addressed.

Interestingly, it is the very common joint occurrence of different species of Stigonema in a same sample or within a centimeter spatial scale. In sample SAMA 38, for instance, four species (S. hormoides, S. informe, S. ocellatum and Stigonema sp.) were found growing together. Stigonema hormoides, S. ocellatum and $S$. turfaceum were all present in the samples SAMA 34, SAMA 35 and SAMA 36. Thus, it is possible to speculate that many species have similar environmental requirements, but a more robust evaluation would only be supported with additional data from populations of the same and other ecologically distinct habitats.

Considering biogeography, only two species found, Stigonema hormoides and S. minutum, were also recorded by Hoffmann (1986) for Luxemburg and this low number of common species among the surveys is probably connected to the distinct climatic areas studied. In comparison with the data presented by Couté et al. (1999), for New Caledonia, five species (Stigonema hormoides, S. minutum, $S$. ocellatum, S. informe and S. turfaceum) were common to both studies, possibly reflecting environmental similarities among the areas. Sant'Anna et al. (1991) found, in a small cave, four species (Spelaeopogon sommierii, Stigonema hormoides, $S$. minutum and $S$. ocellatum) also recorded in this study and this relatively low similarity is surely due to the size of the area studied.
Although it is possible to reach specific identification for most of populations according to the classical monographs on cyanobacteria, the criteria used for species circumscription seem to be very wide. Many recorded species in literature perfectly correspond to original and further descriptions of such taxon, but more detailed analyses of illustrations reveal distinct filament structures and cell arrangements. However, the exact value of each taxonomic criterion used on this group is still to be proved, probably with the help of additional tools.

Some contributions to the cyanobacterial classification system (Komárek \& Anagnostidis 2000, 2005, Hoffmann et al. 2005, Komárek 2006, 2010) emphasize the necessity of also taking into account the environmental and geographical characteristics in the identification process. If on one hand it is a well-supported concept because it probably reflects species requirements, it also creates a practical problem on the other. During this work, these premises were considered to improve the taxonomic evaluation but it is still very difficult to assure that two very similar (or identical) morphotypes are different because the existence of some ecological deviation from the type. The central problem is that it is still not clear if identical genotypes can support distinct environmental pressures without phenotypic changes or in what extension these changes occur. The concept of ubiquitous occurrence of most species has been discarded (Komárek 1994), but few data on genetic variability of true branched complex cyanobacteria have been produced to provide a solid theoretical background about the biogeography of the species.

The results of the molecular assessment obtained from this study suggest that populations identified as same species can be also similar at genetic level even they are from distinct climatic regions. The $S$. ocellatum $\mathrm{SAG}$ 48.90 is a cultivated strain from specimens collected in a Sphagnum peat bog in Germany and the paper of Gugger \& Hoffmann (2004) presents a brief morphological account of the specimens. In general, there is good metrical correspondence and the identification as $S$. 
ocellatum seems to be correct for all. However, the structure of filaments is not always quite similar (cell size in the main filament, cell size in branches, stratification), but it is difficult to evaluate if the variations are really meaningful. A critical review of different Stigonema ocellatum descriptions and illustrations found in literature (Frémy 1930, Geitler 1932, Skinner \& Entwisle 2001, Komárek \& Hauer 2011, this paper) corroborates that a very wide morphological range is recorded for the species, even though most of the populations can be correctly identified on the basis of the species original description. The present results from morphological and molecular studies and the available data in literature allow considering that $S$. ocellatum is probably a complex of species rather than a well delimited species. As it is a very widespread "species", more detailed molecular and morphological studies with populations from distinct geographical and ecological habitats are strongly recommended.

Hapalosiphon welwitschii AY034793, which is the closest sequence to Hapalosiphon sp., is a strain from Australian soils, but, unfortunately, no morphological data could be found for further comparison to the Brazilian material. The phylogenetic tree demonstrates that the clade formed by different species of Hapalosiphon, Westiellopsis, Fischerella and Nostochopsis constitute a mixed and much supported group and that the distinction among the different genera and species needs to be improved.

The molecular approach of the heterocytous true branched cyanobacteria group is still at the very initial stage. The usual techniques for DNA extraction require considerable amount of unicyanobacterial growths (cultures), that have been proved to be very uncommon to be achieved, mainly for species of Stigonema or Hapalosiphon, for instance. They apparently have a special set of environmental requirements to grow and their growth rate is usually low, favoring the establishment of cyanobacteria from other groups prior to the final isolation. New methods to study directly from nature have been developed (e.g. DNA sequencing from one or few cells), but they need to be improved and extended. Some time will be taken until we can access a reasonable amount of data to incorporate to the taxonomical approach. Meanwhile, it is important and relevant to record the morphological and molecular (when possible) diversity of populations with special geographical occurrence and ecology.

The cyanobacterial systematics is still confused and its reorganization on the basis of traditional morphological characters seems to be not adequate (Garcia-Pichel et al. 1996, Palinska et al. 1996). Instead, a polyphasic approach has been employed to better define the taxonomic levels (Zehr et al. 2003, Rajaniemi et al. 2005, Marquardt \& Palinska 2007) and the modern taxonomy is becoming a synthetic science that incorporates several tools to achieve a more robust evaluation of the biodiversity. However, mainly in tropical areas, there is an enormous contingent of still not described morphotypes that is extremely relevant for the understanding of evolutionary relationships and producing a more natural classification system for this important group of organisms.

\section{ACKNOWLEDGMENTS}

The authors thank to Conselho Nacional de Pesquisa e Desenvolvimento Tecnológico (CNPq), Coordenação de Aperfeiçoamento de Pessoal de Nível Superior (CAPES), Fundação de Amparo à Pesquisa do Estado de São Paulo (FAPESP) and the grant LH12100 to JK for the financial support. We also thank to Tomáš Hauer (University of South Bohemia and Institute of Botany of Academy of Science of Czech Republic) for improving the molecular analysis and tree construction.

\section{RESUMEN}

Las bacterias aerofíticas crecen comúnmente en las rocas, troncos de árboles y el suelo, pero la diversidad de estos organismos todavía es poco conocida. Este complejo grupo es muy problématico considerando la disposición taxónomica y la circunscripción de las especies, 
especialmente cuando se toman en cuenta las poblaciones tropicales. En esta investigación, 20 muestras de cianobacterias aerofíticas de 15 distintos sitios de muestro fueron recolectadas a lo largo de un área de selva tropical en el estado de São Paulo (Brasil). Las muestras fueron secadas a temperatura ambiente después de su recolecta, y una vez en el laboratorio, se hidrataron y analizaron. El estudio taxónomico resultó en un registro y descripción de nueve especies de cianobacterias con ramificaciones verdaderas pertenecientes al género Spelaeopogon (una especie), Hapalosiphon (dos especies) y Stigonema (seis especies). La similutud de la flora encontrada en comparación con las encuestas realizadas en otras regiones geográficas fue relativamente baja. Estas diferencias podrían deberse a las condiciones ecológicas de los hábitats, a la extensión de la zona de estudio o incluso a malas interpretaciones taxonómicas. La evaluación molecular del 16S rDNA del material de campo fue un éxito para dos morfoespecies, Hapalosiphon sp. y Stigonema ocellatum, sin embargo, sus relaciones con otras poblaciones y especies revelan que son inciertas. Los resultados del estudio florístico y de la aproximación molecular evidencian la débil delimitación de algunos géneros y especies en el grupo de cianobacterias con ramificaciones verdaderas.

Palabras clave: $16 \mathrm{~S}$ rDNA, Brazil, diversidad, bosque tropical, Nostocales, "Stigonematales", taxonomía.

\section{REFERENCES}

Anagnostidis, K. \& J. Komárek. 1990. Modern approach to the classification system of cyanophytes. 5-Stigonematales. Algolog. Stud. 59: 1-73.

Birnboim, H.C. \& J. Doly. 1979. A rapid alkaline extraction procedure for screening recombinant plasmid DNA. Nucl. Acids Res. 7: 1513-23.

Branco, L.H.Z. \& O. Necchi-Júnior. 1999. New occurrence of the rare genus Doliocatella (Stigonematales, Cyanophyceae). Nova Hedwigia 68: 393-397.

Branco, L.H.Z., L. Hoffmann, J.P. Teixeira., V. Ferreira \& J.C. Morais-Filho. 2009. Aerophytic cyanoprokaryotes from Atlantic rainforest region of São Paulo State, Brazil: Chroococcales and Oscillatoriales. Cryptogamie, Algol. 30: 135-152.

Branco, L.H.Z., L. Hoffmann, O. Necchi-Júnior, S.R. Taboga \& E.N.M. Moura. 2010. Branch formation in Pulvinularia suecica (Nostocales, Cyanoprokaryota) and considerations on the classification of dichotomously and pseudodichotomously branched genera. Nova Hedwigia 90: 95-104.

Büdel, B., U. Becker, S. Porembski \& W. Barthlott. 1997. Cyanobacteria and cyanobacterial lichens from inselbergs of the Ivory Coast. Bot. Acta 110: 458-456.

Büdel, B., U. Lüttge, R. Stelzer, O. Huber \& E. Medina. 1994. Cyanobacteria of rocks and soils of the Orinoco lowlands and the Guyana uplands, Venezuela. Bot. Acta 107: 422-431.

Büdel, B., H.M. Weber, S. Porembski \& W. Barthlott. 2002. Cyanobacteria of inselbergs in the Atlantic rainforest zone of eastern Brazil. Phycologia 41: 498-506.

Couté, A., G. Tell \& Y. Thérézien. 1999. Cyanophyceae (Cyanobacteria) aérophiles de Nouvelle-Calédonie. Cryptogamie, Algol. 20: 301-344.

Finsinger, K., I. Scholz, A. Serrano, S. Morales, L. UribeLorio, M. Mora, A. Sittenfeld, J. Weckesser \& W.R. Hess. 2008. Characterization of true-branching cyanobacteria from geothermal sites and hot springs of Costa Rica. Environ. Microbiol. 10: 460-73.

Frémy, P. 1930. Les Myxophycées de l'Afrique équatoriale française. Archives de Botanique Mémoire_3: 1-508.

Garcia-Pichel, F., L. Prufert-Bebout \& G. Muyzer. 1996. Phenotypic and phylogenetic analyses show Microcoleus chtlonoplastes to be a cosmopolitan cyanobacterium. Appl. Environ. Microbiol. 62: 3284-3291.

Gardner, N.L. 1927. New Myxophyceae from Porto Rico. Mem. N. Y. Bot. Gard. 7: 1-144.

Geitler, L. 1932. Cyanophyceae, p. 673-1056. In L. Rabenhorst (ed.). Kryptogamen-flora von Deutschland, Österreich und der Schweiz. Akademische Verlagsgesellschaft, Leipzig, Germany.

Golubić, S. 1967. Die Algenvegetation an Sandsteinfelsen Ost-Venezuelas (Cumaná). Int. Revue ges. Hydrobiol. 52: 693-699.

Golubić, S. 1976. Taxonomy of extant stromatolite-building cyanophytes, p. 127-140. In M.R. Walter (ed.). Developments in Sedimentology, 20: Stromatolites, Elsevier, Leipzig, Germany.

Gugger, M.F. \& L. Hoffmann. 2004. Polyphyly of true branching cyanobacteria (Stigonematales). Int. J. Syst. Evol. Microbiol. 54: 349-357.

Hall, T. 1999. BioEdit: a user-friendly biological sequence alignment editor and analysis program for Windows 95/98/NT. Nucl. Acids Symp. S. 41: 95-98.

Hoffmann, L. 1986. Cyanophycées aériennes et subaériennes du Grand-Duché de Luxembourg. Bull. Jard. Bot. Nat. Belg. 56: 77-127.

Hoffmann, L., J. Komárek \& J. Kastovský. 2005. System of cyanoprokaryotes (Cyanobacteria)-state in 2004. Algolog. Stud.117: 95-115.

Kaštovský, J., K. Fučíková, T. Hauer \& M. Bohunická. 2011. Microvegetation on the top of Mt. Roraima, Venezuela. Fottea 11: 171-186.

Komárek, J. 1994. Do all Cyanophytes have a cosmopolitan distribution? Survey of the freshwater Cyanophyte flora of Cuba. Algolog. Stud. 71: 359-386.

Komárek, J. 2006. Cyanobacterial taxonomy: current problems and prospects for the integration of traditional and molecular approaches. Algae 21: 349-375. 
Komárek, J. 2010. Recent changes (2008) in cyanobacterial taxonomy based on a combination of molecular background with phenotype and ecological consequences (genus and species concept). Hydrobiologia 639: 245-259.

Komárek, J. \& K. Anagnostidis. 2000. Cyanoprokaryota. 1. Teil: Chrooccocales, 19/1, p. 1-548. In H. Ettl, G. Gärtner, H. Heynig \& D. Mollenhauer (eds.). Süßwasserflora von Mitteleuropa , Gustav Fischer Verlag, Stuttgart-Jena, Germany.

Komárek, J. \& K. Anagnostidis. 2005. Cyanoprokaryota. 2. Teil: Oscillatoriales, 19/2, p. 1-759. In B. Büdel, G. Gärtner, L. Krienitz \& M. Schagerl (eds.). Süßwasserflora von Mitteleuropa , Elsevier GmbH-Spektrum Akad. Verl., Munich, Germany.

Komárek J. \& T. Hauer. 2011. CyanoDB.cz-On-line database of cyanobacterial genera. World-wide electronic publication, University of South Bohemia \& Institute of Botany AS CR (Downloaded: May18th, 2012, http://www.cyanodb.cz).

Kufferath, H. 1929. Algues et Protistes muscicoles, corticoles et terrestres récoltés sur la montagne de Barba (Costa Rica). Ann. Crypt. Exotique 2: 23-52.

Lane, D.J. 1991. 16S/23S sequencing, p. 115-175. In Stackebrandt, E. \& M. Goodfellow (eds.). Nucleic Acid Techniques in Bacterial Systematics, Willey and Sons, Chichester, England.

Marquardt, J. \& K.A. Palinska. 2007. Genotypic and phenotypic diversity of cyanobacteria assigned to the genus Phormidium (Oscillatoriales) from different habitats and geographical sites. Arch. Microbiol. 187: 397-413.

Neilan, B.A., J. Jacobs, T. Del Dot, L.L. Blackall, P.R. Hawkins, P.T. Cox \& A.E. Goodman. 1997. rDNA sequences and evolutionary relationships among toxic and nontoxic cyanobacteria of the genus Microcystis. Int. J. Syst. Bacteriol. 47: 693-697.

Palinska, K.A., W. Liesack, E. Rhiel \& W.E. Krumbein. 1996. Phenotype variability of identical genotypes: the need for a combined cyanobacterial taxonomy demonstrated on Merismopedia-like isolates. Arch. Microbiol. 166: 224-233.
Pattanaik, B. \& S.P. Adhikary. 2002. Blue-green algal flora at some archaeological sites and monuments of India. Feddes Repert. 113: 289-300.

Rajaniemi, R., P. Hrouzek, K. Kaštovská, R. Willame, A. Rantala, L. Hoffmann, J. Komárek \& K. Sivonen. 2005. Phylogenetic and morphological evaluation of the genera Anabaena, Aphanizomenon, Trichormus and Nostoc (Nostocales, Cyanobacteria). Int. J. Syst. Evol. Microbiol. 55: 11-26.

Sambrook, J., E.F. Fritsh \& T. Maniatis. 1989. Molecular cloning-a laboratory manual. Cold Spring Harbor, New York, USA

Sant'Anna, C.L., S.M.F. Silva \& L.H.Z. Branco. 1991. Cyanophyceae da Gruta-que-chora, município de Ubatuba, estado de São Paulo, Brasil. Hoehnea 8: 75-97.

Sarthou, C., Y. Thérézien \& A. Couté. 1995. Cyanophycées de l'inselberg des Nourages (Guyane Française). Nova Hedwigia 61: 85-109.

Seo, P.S. \& A. Yokota. 2003. The phylogenetic relationships of cyanobacteria inferred from 16S rRNA, gyr $\mathrm{B}$, rpo $\mathrm{C} 1$ and rpoD1 gene sequences. J. Gen. Appl. Microbiol. 49: 191-203.

Silva, S.M.F. \& C.L. Sant'Anna. 1991. Stigonemataceae (Cyanophyceae) do Estado de São Paulo, I: o gênero Hapalosiphon. Hoehnea 17: 121-149.

Silva, S.M.F. \& C.L. Sant'Anna. 1996. Stigonemataceae (Cyanophyceae, Stigonematales) do estado de São Paulo, Brasil: gênero Stigonema Bornet \& Flahault. Hoehnea 23: 27-52.

Skinner, S. \& T.J. Entwisle. 2001. Non-marine algae of Australia: 2. Some conspicuous tuft-forming Cyanobacteria. Telopea 9: 685-712.

Tomitani, A. 2004. Evolution of branching filamentous cyanobacteria: molecular-phylogenetic analyses of stigonematalean species. IFREE Report 2003-2004 2: $1-5$.

Zehr, J.P., B.D. Jenins, S.M. Short \& G.F. Steward. 2003. Nitrogenase gene diversity and microbial community structure: a cross-system comparison. Environ. Microbiol. 5: 539-554. 